\title{
A Native perspective: Food is more than consumption
}

\author{
Rachel V. Vernon* \\ Cooperative Food Empowerment Directive (CoFED)
}

Submitted June 19, 2015 / Published online September 9, 2015

Citation: Vernon, R. V. (2015). A Native perspective: Food is more than consumption. Journal of Agriculture, Food Systems, and Community Development, 5(4), 137-142. http://dx.doi.org/10.5304/jafscd.2015.054.024

Copyright (C) 2015 by New Leaf Associates, Inc.

\begin{abstract}
Effectively engaging in food work with and among Native American people toward food sovereignty requires cultural competency, historical knowledge, and a more complex understanding of how food informs community well-being. Drawing on both personal and academic experience, this paper argues that Native Americans' food consumption is tied to land, place, relationships, community, and health. Native American relationships to food stand in contrast to American individualism and function as an intricate part of communities to maintain relationships, build cultural knowledge,

* Rachel V. Vernon, CoFED, the Cooperative Food Empowerment Directive; 2323 Broadway, Suite 223; Oakland, California 94612 USA; rachel@,cofed.org

\section{Disclosures}

Parts of this commentary were drawn from the author's master's thesis, Food systems among Native American peoples in Oakland, California: An examination of connection and health, as cited in the reference. Some of this commentary was written during paid staff time at CoFED.
\end{abstract}

and satisfy emotional and physical health. Food problems among Native people have developed over centuries of forced change, a history that provides insight into the way food has been utilized to colonize. As a result, many tribes and individuals have become food dependent on the U.S.

government. Food systems research and outreach that focuses narrowly on consumption and access risk oversimplifying Native communities' relationship to food as well as their movement toward food sovereignty. Solutions that do not account for the cultural and historical realities of Native people are not real solutions to the problems confronting them. We must make room, therefore, in the food justice movement to envision alternative solutions that better reflect Native realities, cultures, and lives.

\section{Keywords}

Native American, food justice, food movement, culture, food sovereignty 
A s a person of Yaqui and Mescalero Apache descent, I have a long history of personal engagement with Native people within the context of community as well as working for Native organizations that work on Native issues. My educational journey has also focused on Native people and their relationship to food within the context of food justice. I currently work at the Cooperative Food Empowerment Directive, where we hope to encourage a world where food cooperatives build community wealth. My experiences working on food issues with Native people have led me to the question: How do we build resilient Native communities that are empowering and powerful? In attempting to answer this question I have discovered that the relationship to food for Native communities has been ruptured, making food central to the question of empowerment and power. For many Native people a ruptured relationship to food resulting from colonization has had profound effects beyond nutrition and health. These effects must be examined in more detail to develop a better understanding of food's power in community building given historical realties that have informed current relationships to food for all Native communities in this country.

According to the 2010 census there are over 566 federally recognized tribes, 2.9 million people who identify as Native only, and 5.2 million who claim Native identity in combination with another race (Centers for Disease Control and Prevention [CDC], n.d.). As one works with Native people it is important to acknowledge that we are not one people. Although our experiences with U.S. society have helped to create a pan-Native identity, we are not one. Each tribe has its own language, customs, beliefs, and histories. However, there are many commonalities found among these diverse populations, commonalities such as Native philosophies of interconnectedness, obligations, and responsibilities between people, animals, land, water, and air.

The current perspective, drawn from research for my master's thesis at Colorado State University (Vernon, 2014), uses a qualitative PhotoVoice project with participants from the Intertribal Friendship House (IFH) in Oakland, California. The goal of the project was to further the under- standing of contemporary relationships to food for Native people, while also highlighting some of the tremendous work of Native organizations and people within their communities. Among the 11 tribal identities represented, some individuals had a history of occupation of their ancestral/reservation homelands and others did not have much connection to their homelands. ${ }^{1}$ The majority of participants were women ranging in age from their late 20 s to 60 s. This project illuminated the ways that Native people challenged the myths of individual choices and consumption around food. To expand the narrative around health and food, I have chosen one story to share that I believe informs us about how we can work in solidarity to solve the food issues that Native people encounter.

What my research found was that food cannot be disentangled from people and relationships; consuming, producing, and foraging for food all have meaning because they facilitate the strengthening of community bonds. Some participants believed that eating "well" is not always about the nutrition of the food, that it has more meaning. Photo 1 highlights this idea. A quick or cursory look would suggest that this food means the person is not eating well, due to both the quality of the food and its potential effects on health and well-being.

This photo could be treated as evidence of the "problems" with food consumption among Native people, and this food - the McDonald's coffee and a sweet pastry — could easily be transformed into a warning poster of what not to do. It confirms the dilemma nutritionists have identified with the diet of marginalized people, a diet that includes too much sugar and fast food and illuminates the unhealthy choices of an entire community. Too easily this image could be used to fuel a narrative of what is wrong with the food choices of Native people, placing the blame for health problems upon this community. However, there is an alternative reading of this image, one that tells a story of nourishment, relationships, and safety.

The hand in the photo belongs to the 82 -year-

\footnotetext{
${ }^{1}$ The tribes represented were Zapotec, Ohlone, Chumash, Hopi, Tewa, Navajo, Yurok, Seminole, Stockbridge MunseeMohican, Sioux, and Shoshone.
} 
old aunt of Ana, a participant who shared this picture during a focus group at the Intertribal Friendship House (IFH). Ana shared at that meeting how this picture was taken after she had endured a long day of arranging for the secure and affordable parking of her car, which required both negotiating informal arrangements at IFH and dedicating precious time to traveling on public transportation. Exhausted by the process, Ana still found a sense of happiness, love, and community as her aunt presented her with some food.

I had to bring my car to IFH and leave it in the parking lot, and Carol was nice enough to let me do that because I don't have secure parking. And then, taking the BART and a bus home, and then the BART to the San Francisco Airport and then getting a red eye-it was just really exhausting and such a long journey. It felt so good to get to that airport and my aunt that I'm really close to, she's 82 . So that's her there in the car and so she picked me up and she had brought me a sweet roll that another aunt had packed for me, that she had driven. So I just thought it was so sweet that my aunty making it the day before or something, and my other one [auntie] packing it and driving it about an hour to the airport and so it was already ready for me all packaged in the car. Then a senior priced coffee from McDonald's. You know she got her discount or whatever and got it for me. So, I know it's not healthy or something but it was, you know, just a meaningful moment and I really felt like I could totally relax at that moment.

This strikingly beautiful story illuminates the healing nature that food and connection have on people's lives. It illuminates deeper notions of nourishment, situating the relationships of the producers of the food as sacred, while also demonstrating how this food, this experience, is tied to home, to being on or near her reservation. This moment also signals satisfied emotional health. In sum, what this story teaches is that the meaning of food among Native people must be discussed with more depth. Food means more than simply personal responsibilities about food choices and includes a more complex understanding of how food invokes community, well-being, and connectedness. The key point in the interaction is not the food itself, or the act of consuming the food and the resultant health factors, but instead the role the food has in community and individual wellbeing.

The severe disruption of Native communities and lives extends to the altering of their relationship to food, and is deeply tied to racism, colonialism, and the loss of autonomy and power. Stripping Native communities of their food sovereignty and traditional diets increased nutritional deficiencies and starvation for Native people and contribute to current health disparities in obesity, heart disease, and diabetes. (First Nations Development Institute, 2014). Destruction that began at contact became apparent when the Native population dropped from over 5 million to 250,000 in 1900 (Thornton, 1987, p. 133), a decrease resulting from

\section{Photo 1. Ana receives a sweet bun and coffee upon her arrival home.}

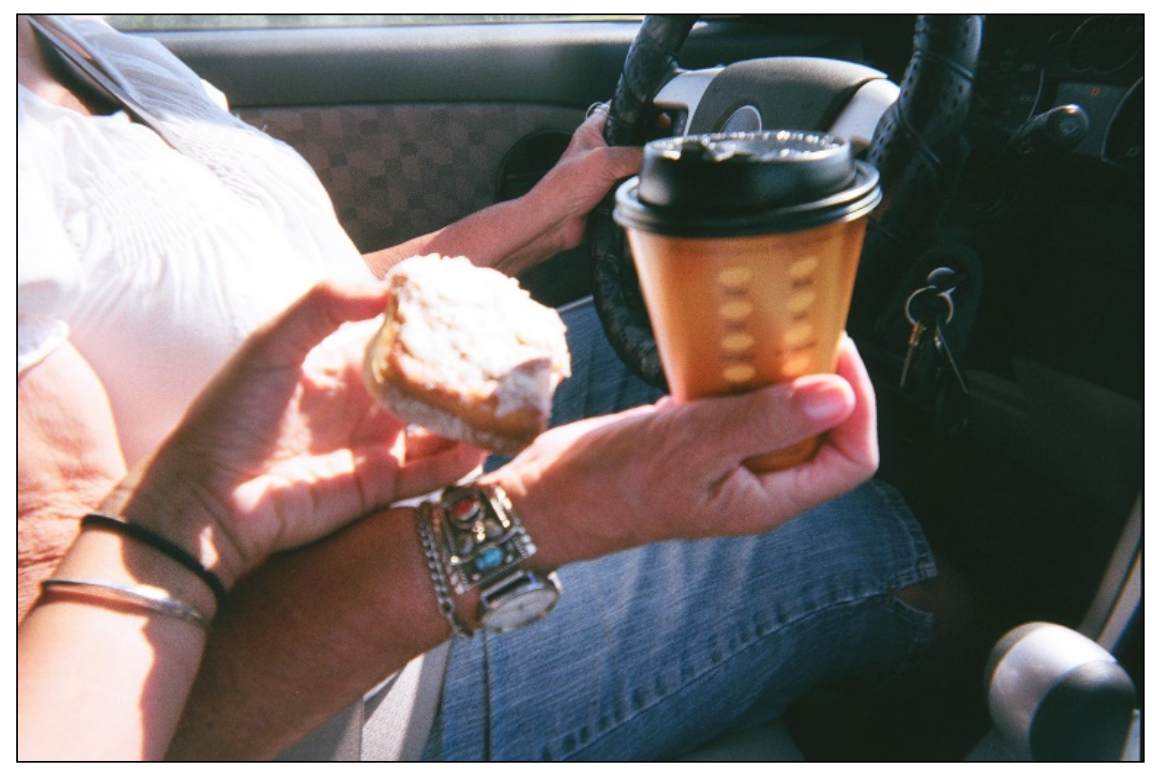


disease and war that had a dire impact on the ability of Native people to hunt, gather, grow, cure, and cook food. Many Native people were also relocated off their traditional lands onto bounded reservations. The policy to limit land access affected their hunting and gathering since they were no longer allowed to hunt in traditional places, and much of the reservation lands were not the best for planting. Some relocated tribes were also unfamiliar with the land they were relocated to, thus limiting their ability to find or produce traditional food.

Eventually, the U.S. government launched the Food Distribution Program on Indian Reservations, which is still currently available to "low-income households, including the elderly, living on Indian reservations, and to Native American families residing in designated areas near reservations and in the State of Oklahoma" (U.S. Department of Agriculture, 2015, para. 1). This program provides canned goods, powdered milk, white sugar, and commodity cheese. According to food sovereignty activist Winona LaDuke, "these highly processed, high sugar, high fat, and packaged foods" (LaDuke, 2005 , p. 194) provided by the government have contributed to the high rates of diabetes rates found in Native communities and is a direct impact of the "loss of access to traditional foods" (LaDuke, 2005, p. 194). This loss affects the practice of consuming traditional foods and the teaching of food preparation and foodways across generations, between genders, and within families. This loss of traditional food practices is connected to a loss of human connection, a loss of community strength.

Both reservation and urban Natives have encountered a loss of control over the food they interact with through consumption, production, and distribution. Contrary to the common belief that Natives live on reservations, approximately 78 percent of Native peoples live off-reservation, which may further affect their ability to access traditional foods and knowledge (Norris, Vines, \& Hoeffel, 2012). Urban Native communities have struggled to have access to quality food since moving to urban areas. ${ }^{2}$ The Governmental

\footnotetext{
${ }^{2}$ Some of these individuals have moved willingly, while others
}

Relocation Program in the 1950s moved thousands of Native people into urban areas with the hope of assimilating them into modern American society (Fixico, 1986). These programs have generally failed since Native people have been integrated into mostly poor urban areas and have been subject to the food deserts of the already existing marginalized communities of color.

This historical context helped shape Native communities' current relationship to food and should be central to addressing food related concerns within these communities. Too often, those involved in food justice work see the lack of consumption of healthy foods as an issue of personal choice rather than one resulting from a deeply traumatic history of food relations in Native communities. The common U.S. narrative about Native people is that we do not care about our health and subsequently make poor eating decisions. In her chapter in Cultivating Food Justice (2011), Guthman explores how universalism and colorblind logic inform the assumptions of white communities regarding "why" people of color do not frequent places such as farmers markets in the same numbers as white communities. Guthman's ethnographic study on farmers markets found that many white vendors relied on evaluative statements about whites having higher education levels and exhibiting greater interest in health as factors that lead to primarily white patronage of farmers markets. Guthman's study argued that farmers market vendors believe that low education levels lead to a disinvestment in health, participation, and education about food. Such ideologies and discourses around race, health, and food for Native and marginalized communities oversimplifies the relationship to food and deny the systemic way colonial oppression works.

There is no doubt that, given the limited scholarship, further research on food (in) security among Native people is needed. This exploration must include a cultural understanding about food and its importance for community well-being. There is a dire need to connect food to community well-being rather than just individual health. Since

moved due to forced removal from their tribal communities by the U.S. government. 
some research finds that many "Native American communities experience a lack of access to highquality and culturally appropriate foods" (Jernigan, 2012, p. 113) and these communities have "higher rates of chronic-disease-related outcomes, including obesity, diabetes, and cardiovascular diseases" (Jernigan, 2012, p. 113), more research on foodways is vital for understanding how these poor health outcomes and lack of access have affected communities' functioning and well-being. Those interested in working with Native people must develop a deeper, historically grounded understanding of Native food consumption, including knowledge about their specific food histories and elaborate foodways.

For many Native communities, including the participants of my study, food is the sinew that holds communities together. Food helps build cultural knowledge and practice, satisfies health holistically by satisfying emotional and physical needs, and brings people together through the act of producing, consuming, and distributing foods. This was evident in my work with the IFH and its food programs.

While food brings people together, it can also be a source of great pain, shame, loss, and disconnection. This was most evident through the story of a participant who lamented that her daughter did not like salmon, a traditional and sacred food of her tribe. Those devising strategies to build food sovereignty must have a deep historical understanding of how food has been lost, how people have been moved or constrained, and how food acts as a community-bonding factor. The narrow focus on food consumption and access as they relate to physical health limits Native attempts to achieve food justice for our communities.

To address the food needs and well-being of Native peoples, we must expand the contemporary scholarship and policy efforts addressing health disparities that focus only on personal accountability and personal choice in eating and exercising. While it is important to address access, accountability, and choice, these approaches are not a holistic solution for Native well-being. Mainstream attempts to address issues involving food among Native people are singular in analysis and deny the complex effects of colonialism. These attempts also deny the function and role that many "unhealthy" foods have in Native communities. Changing diets means creating new meaning and integrating new foods into old practices. In the case of Native people living near their homelands, it might also mean integrating old foods into current practices.

The food movement must support Native people in their work toward rebuilding tribal food systems. In Oakland, Native people have created a community garden, cooking classes, community dinners, a food pantry, and a cookbook in an effort to build their own urban food system. Several tribes are utilizing food as a means to change the economy, revitalize traditions, and provide more food security. Examples of this work can be seen among the traditional foods programs supported by the CDC among the Mohegan, Muscogee (Creek) Nation, Oneida, Laguna Pueblo, and Suquamish tribes (CDC, 2013). These projects share similar themes found in my own work (Vernon, 2014) that include strengthening cultural identity, sharing knowledge, and fostering intergenerational knowledge. Programs across the country in both urban spaces and on reservation lands are improving health and building community through engaging in food sovereignty. We must support these projects and help build leadership among Native people by providing them with resources and greater visibility for their projects. Those people interested in assisting these efforts must develop cultural competencies within the communities where projects are located that include historical and contemporary understandings of power relations that support rebuilding Native food systems in culturally relevant and meaningful ways.

\section{References}

Centers for Disease Control and Prevention [CDC]. (2013). Traditional foods in Native America: $A$ compendium of stories from the Indigenous food sovereignty movement in American Indian and Alaska Native communities_-Part I. Atlanta: Native Diabetes Wellness Program, Centers for Disease Control and Prevention.

CDC. (n.d.). American Indian \& Alaska Native population. Retrieved June 14, 2015, from http://www.cdc.gov Lminorityhealth/populations/REMP/aian.html 
First Nations Development Institute. (2014). Native food and health fact sheets (Nos. 1, 4-7). Longmont, Colorado: Author. Retrieved from http://firstnations.org/knowledge-center/foodshealth/resources/fact-sheets

Fixico, D. L. (1986). Termination and relocation: Federal Indian policy, 1945-1960. Albuquerque: University of New Mexico Press.

Guthman, J. (2011). "If they only knew": The unbearable whiteness of alternative food. In A. H. Alkon \& J. Agyeman (Eds.), Cultivating food justice: Race, class, and sustainability (pp. 263-282). Cambridge, Massachusetts: MIT Press.

Jernigan, V. B. B. (2012). Addressing food security and food sovereignty in Native American communities. In J. R. Joe \& F. C. Gachupin (Eds.), Health and social issues of Native American women (pp. 113-152). Denver, Colorado: Praeger.

LaDuke, W. (2005). Recovering the sacred: The power of naming and claiming. Boston: South End Press.
Norris, T., Vines, P. L., \& Hoeffel, E. M. (2012). The American Indian and Alaska Native Population: 2010 (2010 Census Briefs No. C2010BR-10). Washington, D.C.: U.S. Department of Commerce, U.S. Census Bureau. Retrieved from https://www.census.gov/ $\mathrm{prod} / \mathrm{cen} 2010 /$ briefs/c2010br-10.pdf

Thornton, R. (1987). American Indian holocaust and survival: A population history since 1492. Norman: University of Oklahoma Press.

United States Department of Agriculture [USDA]. (2015). Food Distribution Program on Indian Reservations (FDPIR). Retrieved June 11, 2015, from http://www.fns.usda.gov/fdpir/food-distributionprogram-indian-reservations-fdpir

Vernon, R. V. (2014). Food systems among Native American peoples in Oakland, California: An examination of connection (Master's thesis). Colorado State University, Fort Collins, Colorado. 